九州大学学術情報リポジトリ

Kyushu University Institutional Repository

\title{
DISCOVERY OF THE SECOND SPECIES OF PROSOPISTEROIDES OF NEW GUINEA (HYMENOPTERA, COLLETIDAE)
}

Hirashima, Yoshihiro

https://doi.org/10.5109/2397

出版情報: ESAKIA. 14, pp.145-148，1979-11-15. Entomological Laboratory，Faculty of Agriculture, Kyushu University バージョン：

権利関係 : 


\title{
DISCOVERY OF THE SECOND SPECIES OF PROSOPISTEROIDES OF NEW GUINEA (HYMENOPTERA, COLLETIDAE)*
}

\author{
Y OSHIHIRO HIRASHIMA \\ Entomological Laboratory, Faculty of Agriculture \\ Kyushu University, Fukuoka 812, Japan
}

\begin{abstract}
A new species of bees, Hylaeus (Prosopisteroides) gressitti, is described based on a female specimen taken at Keglsugl, 2,700 m, Mt. Wilhelm, Papua New Guinea. This is the second species of Prosopisteroides, a subgenus of Hylaeus endemic to New Guinea.
\end{abstract}

Hirashima (1967) proposed the subgenus Prosopisteroides for Hylaeus heteroclitus Hirashima, 1967, a very interesting Papuan bee. The subgenus is characteristic in having the extraordinarily elongate maxillary palpi, the unusually large, elongate, subhorizontal propodeal enclosure, the preoccipital carina (which is seen in the median portion of the occiput only, however), and the round and finely striated area lateral to the spiracle on the 2nd metasomal tergum.

The second species of Prosopisteroides was discovered by me on Mt. Wilhelm, Papua New Guinea in 1969 when I was collecting insects at Keglsugl, 2, $700 \mathrm{~m}$, accompanied by Dr. J. L. Gressitt of B. P. Bishop Museum, Honolulu.

It was a sunny morning, about $10: 00$, when I caught a small bee just after it landed on a broad thick green leaf of a tree (undetermined) growing nearby a passway in a native village. I thought I collected a small interesting species of Palaeorhiza because of its brilliant blue-green color of the body. In Keglsugl I was enthusiastic to collect bees, especially Palaeorhiza. The latter was rich in Keglsugl both in the number of species and individual. Thus, at that time, I did not expect Prosopisteroides at all. I recall it still vividly that I was struck with fresh surprise when realized that it is a species of Prosopisteroides as I pinned it at night of the same day.

It is of my pleasure to name this interesting and beautiful species after my respectful friend, Dr. J. L. Gressitt, Wau Ecology Institute, Wau, Papua

* Contribution from the Entomological Laboratory, Faculty of Agriculture, Kyushu University, Fukuoka (Ser. 3, No. 69), and that from the Hikosan Biological Laboratory, Faculty of Agriculture, Kyushu University, Hikosan (Ser. 2, No. 42). 
New Guinea. He kindly invited me to Papua Guinea in 1969. Mr. Osamu Tadauchi kindly taken the photographs of the bee for me.

\section{Hylaeus (Prosopisteroides) gressitti, new species}

Female: Length slightly over $6 \mathrm{~mm}$; length of fore wing, about $5.5 \mathrm{~mm}$; length of maxillary palpi, about $3.5 \mathrm{~mm}$.

Relative head measurements: width, 27 ; length, 26; eye length, 19; upper interocular distance, 17 ; lower interocular distance, 13; length of clypeus, 10. Head round in frontal view (slightly elongate than in heteroclitus); inner eye margins converging below except for upper about one-third which converges toward ocelli; mandible obscurely tridentate at apex; maxillary palpi extraordinarily elongate, distinctly longer than thorax, relative lengths of segments as $3.5: 4$ : $6.5: 17: 14: 16$ (the same scale with head measurements) ; maxillary palpi also

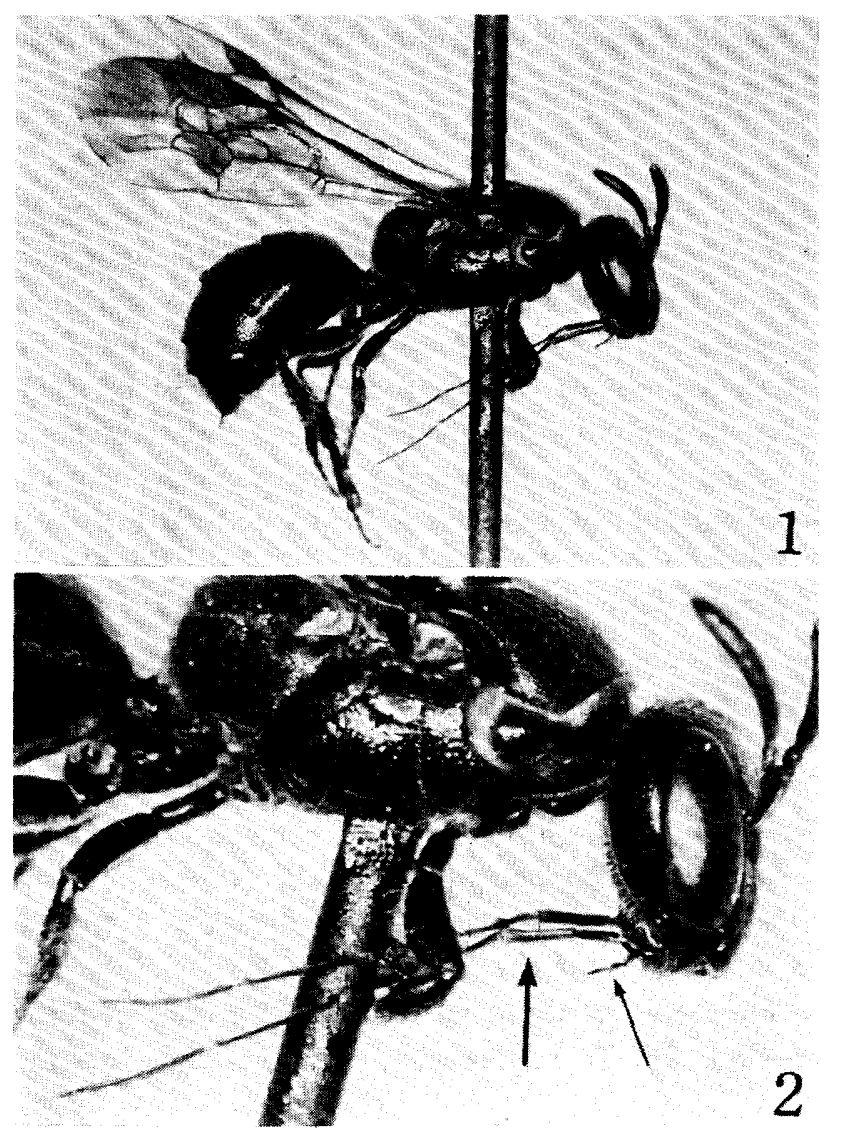

Figs. 1 and 2. Hylaeus (Prosopisteroides) gressitti, new species. 1: Lateral view of the holotype female. 2: Close-up of the same, showing more in detail the enormous maxillary palpi (by a larger arrow) and the usual labial palpi (by a smaller arrow). 
robust and broadened; labial palpi small as usual ; malar space very narrow, widened posteriorly; clypeus well convex as seen in profile; supraclypeal area not so much convex (distinctly convex in heteroclitus), with upper portion not sharply differentiated from frons ; frontal line distinct; a concaved triangular space just below mid ocellus ; frons well convex ; vertex also well convex; preoccipital carina not very sharp; genal area narrower than eye in lateral view, convex above, receding below; mid ocellus slightly smaller than hind ocellus. Relative measurements of ocellar region : width of mid ocellus, 3 ; distance between mid and hind ocelli, about 2.5 ; width of hind ocellus, about 4 ; postocellar distance, 6; ocellocular distance, about 8; ocelloccipital distance, about 5 .

Thorax long, cylindrical ; underside of thorax deeply longitudinally concave as described for heteroclitus; collar of pronotum well convex, thick and rounded laterally; mesoscutum well convex, long ; scutellum large, flat ; metanotum also nearly flat, broad ; propodeum long, rounded posteriorly; propodeal enclosure large, subhorizontal basally.

Legs robust; polliniferous hairs on fore tarsi well developed but not specially dense ; hind tibia moderately robust and without special modification at base.

Wings as usual for Hylaeus.

Metasoma rather compact and well convex.

Clypeus distinctly and somewhat coarsely punctate, finely longitudinally lineolate; supraclypeal area more densely punctate than in clypeus, punctures smaller, also finely lineolate ; frons distinctly and rather irregularly punctate on smooth and shining ground; impunctate polished small space lateral to hind ocellus; vertex strongly punctate ; paraocular area also distinctly punctate except for space lateral to antenna1 socket very finely lineolate. Mesoscutum with coarse and strong punctures not specially dense, those on anterior margin very small and dense; mesoscutum more weakly lineolate and more shining than clypeus ; scutellum sculptured nearly as in posterior portion of mesoscutum; metanotum very weakly and rather densely punctate on weakly nearly shagreened ground, duller than in scutellum ; propodeal enclosure weakly tessellate or weakly shagreened, without sculpture, shining ; dorso-lateral face of propodeum distinctly punctate ; lateral face of propodeum densely and distinctly rugoso-punctate ; pre- and mesepisternum more shining than mesoscutum with weaker lineolation, coarsely punctate, punctures not deep. Metasomal terga distinctly punctate, punctures on 1st tergum somewthat weak, irregular in distribution, those on 2 nd stronger and denser than those on lst, those on 3rd and 4th distinctly much coarser than those on 2nd; impunctate apical margin only narrowly visible on 1st tergum medially, broad, distinctly marked and polished on 2nd and 3rd, distinct but finely shagreened on 4th; sterna also distinctly punctate. 


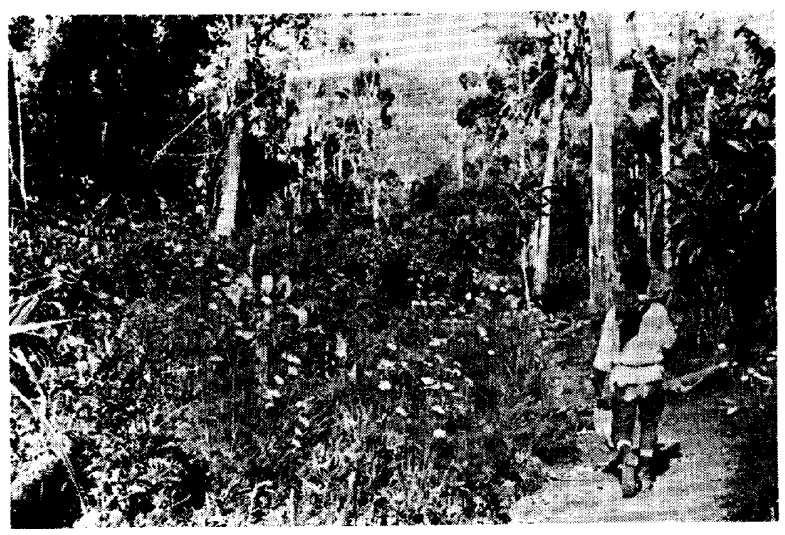

Fig. 3. A sketch of Keglsug1, 2,700 m, the habitat of Hylaeus (Prosopisteroides) gressitti, new species.

Co'or: Head, thorax and metasoma brilliant blue-green ; face without yellow maculation; antennae black with purple tint, flagellum beneath reddish brown; maxillary palpi brown, joints of palpal segments whitish; wings distinctly brownish, paler basally; stigma and veins brown ; tegulae brown with strong blue-green tint; legs piceous with strong blue-green and slight purple reflections.

Pubescence: Hairs on head and thorax brownish, slightly whitish on propodeum and sides of thorax; hairs on metasoma brown, those on apical half long and fuscous; hairs on legs whitish.

Type MAterial: Holotype male (BISHOP 11545), Keglsugl, 2,700 m, Mt. Wilhelm, Chimbu District, Papua New Guinea, 12 August 1969 (Y. Hirashima), in the collection of the Department of Entomology, B. P. Bishop Museum, Honolulu, Hawaii.

Distribution : Papua New Guinea.

REMARKS: This new species is separated from the consubgeneric species Hylaeus heteroclitus Hirashima, which was described from Eliptamin Valley, 1, 200$1,300 \mathrm{~m}$, New Guinea, by the smaller size (about $7 \mathrm{~mm}$ in heteroclitus), the darker coloration (dark blue in heteroclitus), the absence of yellow maculation on the face (yellow stripes present on the sides of face in heteroclitus), the darker hairs (hairs on the head and thorax white in heteroclitus) and the smoother propodeal enclosure (rather coarsely rugose on the apical portion in heteroclitus). Unfortunately the males of Prosopisteroides are not known.

\section{Literature}

Hirashima, Y. 1967. A new subgenus and species of Hylaeus from New Guinea (Hymenop-

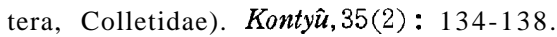

